\title{
miRNAs as biomarkers for early cancer detection and their application in the development of new diagnostic tools
}

\author{
Leonardo J. Galvão-Lima ${ }^{1 *}$ (D), Antonio H. F. Morais ${ }^{1}$, Ricardo A. M. Valentim² and Elio J. S. S. Barreto ${ }^{3}$
}

\author{
${ }^{*}$ Correspondence: \\ leonardo.lima@navi.ifrn. \\ edu.br \\ 'Advanced Nucleus \\ of Technological Innovation \\ (NAVI), Federal Institute \\ of Rio Grande do Norte \\ (IFRN), Avenue Senador \\ Salgado Filho 1559, Natal, RN \\ 59015-000, Brazil \\ Full list of author information \\ is available at the end of the \\ article
}

\begin{abstract}
Over the last decades, microRNAs (miRNAs) have emerged as important molecules associated with the regulation of gene expression in humans and other organisms, expanding the strategies available to diagnose and handle several diseases. This paper presents a systematic review of literature of miRNAs related to cancer development and explores the main techniques used to quantify these molecules and their limitations as screening strategy. The bibliographic research was conducted using the online databases, PubMed, Google Scholar, Web of Science, and Science Direct searching the terms "microRNA detection", "miRNA detection","miRNA and prostate cancer", "miRNA and cervical cancer", "miRNA and cervix cancer", "miRNA and breast cancer", and "miRNA and early cancer diagnosis". Along the systematic review over 26,000 published papers were reported, and 252 papers were returned after applying the inclusion and exclusion criteria, which were considered during this review. The aim of this study is to identify potential miRNAs related to cancer development that may be useful for early cancer diagnosis, notably in the breast, prostate, and cervical cancers. In addition, we suggest a preliminary top 20 miRNA panel according to their relevance during the respective cancer development. Considering the progressive number of new cancer cases every year worldwide, the development of new diagnostic tools is critical to refine the accuracy of screening tests, improving the life expectancy and allowing a better prognosis for the affected patients.
\end{abstract}

Keywords: MiRNA, Biomarkers, Liquid biopsies, Prostate cancer, Cervical cancer, Breast cancer, Early cancer diagnosis

\section{Background}

Over the last decades, microRNAs (miRNAs) have emerged as important molecules associated with regulation of gene expression in humans and other organisms, expanding the strategies available to diagnose and handle several diseases. Briefly, miRNAs are small non-coding RNAs (21-25 nucleotides) and derived from coding and non-coding transcription units in genic (intronic or exonic) and intergenic regions [1, 2].

These molecules were initially described in nematodes and implicated in the regulation of genic expression by post-transcriptional mechanisms targeting complementary

(O) The Author(s) 2021. This article is licensed under a Creative Commons Attribution 4.0 International License, which permits use, sharing, adaptation, distribution and reproduction in any medium or format, as long as you give appropriate credit to the original author(s) and the source, provide a link to the Creative Commons licence, and indicate if changes were made. The images or other third party material in this article are included in the article's Creative Commons licence, unless indicated otherwise in a credit line to the material. If material is not included in the article's Creative Commons licence and your intended use is not permitted by statutory regulation or exceeds the permitted use, you will need to obtain permission directly from the copyright holder. To view a copy of this licence, visit http://creativecommons.org/ licenses/by/4.0/. The Creative Commons Public Domain Dedication waiver (http://creativecommons.org/publicdomain/zero/1.0/) applies to the data made available in this article, unless otherwise stated in a credit line to the data. 
mRNAs and affecting several biological processes, as cell signaling, differentiation, proliferation, and activation/inhibition of apoptotic mechanisms [2-4]. Currently, over 38 thousand miRNAs sequences from 271 species were described and cataloged on the miRBase (http://www.mirbase.org), which 1917 sequences are from Homo sapiens and may represent an important source of data to understand complex cellular mechanisms and establish a molecular diagnosis of several diseases $[5,6]$.

In this sense, considering the miRNAs proprieties and their role in the post-transcriptional regulation of genic expression, along the recent years we observed a successive accumulation of new evidence from differential expression of miRNAs in physiological and pathological conditions-including in infectious diseases and during the cancer development [7-14].

Classically, miRNAs can modulate the genic expression acting directly by intracellular mechanisms or after their release into microvesicles, allowing the modulation of gene expression between different tissues [15-17]. Both intra- and extracellular miRNAs can be detected on tissue samples and biological fluids (as serum, plasma, urine, saliva, sweat, and tears), but currently, this methodology is poorly explored in personalized medicine as diagnosis strategy or therapeutic tool [18-20]. Thereby, this review explores the role of miRNAs on the maintenance of tissue homeostasis, during cancer development, the major strategies adopted to detect and quantify these molecules, and their potential application as biomarkers for early cancer detection using a tissue or minimally invasive samples. Taken together, these findings may contribute to the development of new diagnostic tools for the quantification of miRNAs using clinical samples and allowing the application of personalized medicine strategies.

The current paper summarizes the latest findings related to the application of miRNAs as biomarkers for cancer detection, notably breast, prostate, and cervical cancers. These cancers, despite their high incidence worldwide, resulting in millions of new diagnoses and deaths every year worldwide [21,22], present only few studies summarizing the recent findings in this area. Besides, we take an overview of current strategies used to quantify these molecules in tissue samples and liquid biopsies and point out the major challenges to applying these strategies as a screening method for early cancer detection.

\section{The biological basis of miRNAs and their use as biomarkers of cancer development}

Role of miRNAs during tissue homeostasis, extracellular signaling and their implication on the development of cancer

During physiological conditions, miRNAs play a key role in the control of tissue homeostasis and cell signaling, acting as a post-transcriptional mechanism of gene expression. The coordinate function of these molecules associated with other mechanisms avoid the development of aberrant cellular proliferation, regulates the cellular differentiation and allows the fine regulation of mRNAs in response to endocrine hormones and other stimuli (e.g., cytokines, chemokines, infectious or stress conditions) detected in the cellular microenvironment [23-26].

Typically, miRNAs are expressed in the precursor form (pri-miRNAs) by RNA Polymerase II in the nucleus and partially cleaved by DGC58/Drosha proteins, resulting in the pre-miRNA form, as represented in step 1 of Fig. 1 . This intermediary (70-100 


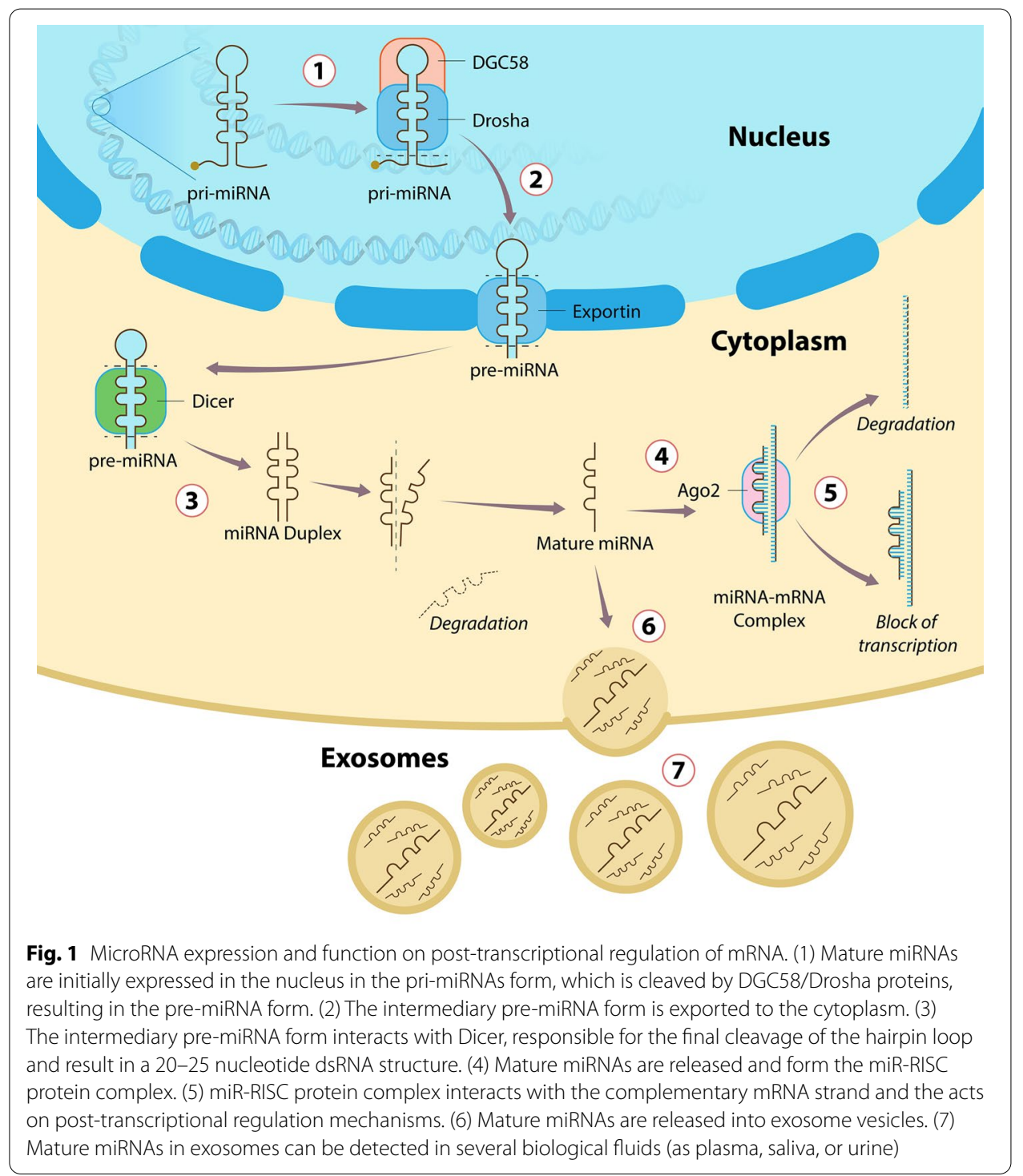

nucleotides) is exported to the cytoplasm by Exportin 5 proteins (step 2) and interacts with Dicer, which will be responsible for the final cleavage of the hairpin loop and results in a 20-25 nucleotide dsRNA structure (step 3). Finally, mature single strain miRNAs are released after the action of helicases and interact with Argonauts proteins (AGO1 and AGO2), resulting in the formation of the miR-RISC protein complex (step4), which stabilizes the following interaction with the complementary mRNA strand and acts on post-transcriptional control of gene expression, driven the mRNA for degradation or silencing (step 5) [27]. Additionally, mature miRNAs can be released into exosome vesicles (step 6) and affect the tissue microenvironment or present an endocrine action after being secreted on biological fluids (as plasma, saliva, or urine), resulting in local or systemic effects (step 7) [28-30].

Despite being systemically secreted by different cell types, the miRNAs expression follows a tissue-specific pattern, evidencing the key role of these molecules on cell 
differentiation and control of homeostasis [31]. Over recent years, this feature has been explored to map the miRNA expression profile in homeostatic conditions and how infections or other diseases can modulate these molecules. In this sense, Ying and colleagues evidenced that miRNAs (notably miR-155) released by adipose tissue macrophages in exosome vesicles play an important role in insulin sensitivity in vivo and in vitro and modulate the cellular glucose uptake [32]. Several miRNAs also have been implicated in the fine regulation of other endocrine signaling pathways by up- or downregulation of estrogen receptors ER- $\alpha$ and $\beta$ [33]. The expression of these molecules can also be influenced by the circadian cycle and contribute to the development of other non-cancer conditions, such as neurological, cardiovascular, and infectious diseases [7-14].

Although being progressively explored in basic research and their potential as a therapeutic tool, targeting specific genes and blocking the over/aberrant gene expression, miRNAs still is under adopted in clinical practices in personalized medicine-whether due to costs, safety or technical issues [34-36]. Currently, the NIH (clinicaltrials.gov) registered over 850 miRNA-related studies and their use for the development of new diagnostic tools or exploring their potential as a therapeutic approach to several diseases, such as sepsis, autism, diabetes mellitus 2, muscular dystrophy, amyotrophic lateral sclerosis, and cancer.

\section{How the changes in the miRNA expression allow the subversion of the tissue microenvironment and contribute to cancer development?}

The dynamic balance between the apoptotic mechanisms and controlled cellular proliferation is critical to prevent the development of potentially malignant cells and keep the immune surveillance ready to act when an aberrant proliferation is detected. Usually, the host immune response activates cellular mechanisms mediated by NK and CD8 $+\mathrm{T}$ cells to eliminate unwanted cells and control the disordered cellular proliferation without damage the affected tissue. In this context, miRNAs are continuously expressed in rest or proliferating cells (including those related to the development of the immune response) and act to control the disordered cellular replication and differentiation, allowing the maintenance of tissue homeostasis or controlled response to stress or injuries [27]. However, when this tight control does not eliminate all detected threats by apoptotic and/or necrotic mechanisms or aberrant cells avoid the development of immune response, it can result in cancer development [37-39].

Several studies have implicated the changes in the miRNA expression pattern with the alteration observed in tissue microenvironment since the early stages of tumoral progression, allowing the formation of new blood vessels, the aberrant cellular proliferation and blocking the development of the immune response (e.g., inducing local Tregs cells and tumor-associated macrophages) [40-42]. Typically, these alterations occur without any manifestation of clinical symptoms or detection by traditional screening methods $[19,43]$. In both contexts, several miRNAs are critical to block the function of cellular sensors and allow the uncontrolled proliferation or indicate the aberrant proliferation, recruiting immune cells to the affected tissue and avoid the tumoral development.

Among the main miRNAs related to the tumoral development, the overexpression of miR-21 was associated with the occurrence of several types of cancer (such as glioblastoma, breast, and gastrointestinal cancer) [44-46]. According to Xu et al. [47], this 
molecule has oncogenic property by targeting critical genes (as PTEN, RECK, and Bcl2), allowing the aberrant cellular proliferation and tissue invasion of malignant cells. On the other hand, the downregulation of other miRNAs (as miR-141) is associated with cell proliferation and invasion in breast, colorectal, and prostate cancer [48-50], while several studies associate the regulation of p53 expression by the miRNAs [51-54]. Taken together, the dynamic balance mediated by several miRNAs between fine regulation of oncogenes and tumor suppressor genes act as a key regulator of tissue homeostasis and may indicate the early stages of tumoral development even when these alterations are not detected by traditional screening methods [55-57].

According to the recent estimates from Bray et al. [39], the number of new cancer cases is expected to affect up to 24.6 million people by 2030 and resulting in 13 million cancer-related deaths. In this sense, accurate early diagnosis is critical to the establishment of adequate therapeutic protocols, save lives, and improve the life expectancy of diagnosed patients $[16,58]$. In recent years, the understanding of biochemistry and metabolic alterations induced during the aberrant cellular proliferation allowed the development of new chemotherapeutic agents, reducing the side effects and improving the therapeutic protocols [59-61]. However, since the description of the epigenetic mechanisms and the influence of miRNAs on post-transcriptional regulation events, a new era of molecular targets emerges as potential therapeutic agents and/or tissue-specific biomarkers of the development of tumoral cells [62-64].

This analysis leads us to the hypothesis that a complex miRNA panel may have an important role in the cancer diagnosis. However, currently there is no consensus on which molecules should be analyzed and how they can be applied as a biomarker of early cancer development, allowing the clinical staff to start the treatment in the initial stages of the disease and improving the quality of life from diagnosed patients.

\section{miRNAs as biomarkers of early cancer development: changes in the expression pattern} detected in tissue samples and minimally invasive liquid biopsies

Although there is a lack of consensus on miRNA panel to detect the cancer development, this review summarizes the major findings related to the role of miRNAs during cancer development and the top 20 molecules related to breast, prostate, and cervical cancers. The current paper is not intended to present a definitive panel but to systematize our knowledge in the application of miRNAs as biomarkers of cancer development, and its importance in the rise of new strategies of diagnosis.

Considering all recent experimental and clinical data accumulated during research in physiological and pathological conditions, the quantification of miRNAs may be a powerful tool during the establishment of early cancer diagnosis, the evaluation of prognosis, and predictive biomarkers $[58,65]$. Over recent years, changes in the pattern of miRNA expression serve as a molecular signature and have been used as a complementary tool to consolidate the cancer diagnosis [66-68]. This property allowed the identification of multiple primary and metastatic cancers by the origin of the tumoral tissue [69-73].

Besides the indication of cancer development with high sensibility and specificity, miRNAs also can be applied to confirm the initial pathological classification and to indicate the prognosis associated with cancer development $[74,75]$. This approach may be used directly from tissue samples even during retrospective studies with 
formalin-fixed paraffin-embedded (FFPE) specimens archived for long periods or using minimally invasive methods [76].

However, despite these advances, currently, only a few studies associate the miRNA expression in tissue samples with the miRNAs released into exosomes, observed using minimally invasive liquid biopsies (as peripheral blood, saliva, urine, and tears) [15-17]. Although several basic studies evaluated the miRNAs present into vesicles, this gap hampers the use of miRNAs as a new strategic diagnostic tool, considering the needed for tissue samples and the use of specific bioinformatics tools to perform the clinical interpretation of results.

Currently, there is a lack of consensus on miRNA panels to detect the cancer development, but we must consider all published data to find which biomarkers may be useful to early detection of each type of cancer. In this sense, despite the suggestion present in the current paper, we encourage the development of new studies to adequate the targets miRNAs according to the genetic background of each population and the type and stage of cancer development.

Considering these findings, the development of a new tool to quantify miRNAs in clinical samples will be useful to detect several cancers and other diseases, including those that affect the CNS, once these molecules can cross the blood-brain barrier and indicate the occurrence of cellular alterations, in a complementary way to the traditional imaging exams [77-79]. Additionally, despite the current difficulties to correlate the serum miRNA profile to the tissue-specific tumoral alterations, the establishment of a well-defined panel and the adequate bioinformatics tools may be useful to distinguish between similar histological/phenotypical subtypes, providing an additional molecular classification using minimally invasive samples with high sensitivity and specificity [80-82].

\section{Preliminary panel of miRNA expression related to breast cancer development}

As previously discussed, several miRNAs are identified as potential biomarkers of breast cancer development, as evidenced in Table 1. Among these, several act as onco-miRs (allowing the aberrant cellular proliferation). Some of these are represented for miR-21, miR-26a, miR-155, miR-221/miR-222, and miR-495, which are related to tumor proliferation and angiogenesis [46, 83-91].

On the other hand, several miRNAs (as those from let-7 family, miR-1, miR-100, miR-125b, miR-126, miR-145, miR-195, miR-199, miR-200c, miR-203, miR-210, miR-298, miR-331, miR-335, and miR-340) are implicated in the control of cell cycle, response to hypoxia and stress conditions, and induction of apoptotic mechanisms $[46,79,92-110]$.

Additionally, McAnena et al. [111] observed that circulating miR-332 and miR-195 may be used to differentiate between local and metastatic breast cancer, while Sathipati et al. [112] suggest that 34 miRNAs can be used to classify the early and the advanced stage of breast cancer progression. These findings reinforce that a small number of miRNAs can be used as biomarkers to risk prediction or prognosis of breast cancer development [113-115]. 
Table 1 Preliminary panel for miRNA quantification related to breast cancer development

\begin{tabular}{lll}
\hline miRNA & Cellular function & References \\
\hline let-7 family & Inhibition of cell proliferation, migration, and metastasis & {$[46,83]$} \\
miR-1 & Inhibition of tumor growth and metastasis & {$[97,171]$} \\
miR-21 & Promotion of cellular proliferation and tumor angiogenesis & {$[46,83,84]$} \\
miR-26a & Promotion of cell proliferation and differentiation in several tissues & {$[85,86]$} \\
miR-100 & Inhibition of tumorigenesis, cell proliferation and signaling & {$[98,99]$} \\
miR-125b & Inhibition of cellular proliferation and induction of metastasis & {$[83,100,172]$} \\
miR-126 & Inhibition of cell invasion by ADAM9 downregulation & {$[103,104]$} \\
miR-145 & Inhibition of cellular proliferation, migration, and tumor angiogenesis & {$[83,105,106]$} \\
miR-155 & Promotion of cellular proliferation and tumor angiogenesis & {$[83,87]$} \\
miR-195 & Regulation of apoptosis and inhibition of tumor invasion & {$[111]$} \\
miR-199a & Inhibition of tumor invasion and metastasis & {$[84]$} \\
miR-200c & Regulation of apoptosis and metastasis & {$[29]$} \\
miR-203 & Inhibition of tumorigenesis, cell proliferation, and signaling & {$[173]$} \\
miR-210 & Response to hypoxia and stress conditions & {$[107,174,175]$} \\
miR-221/miR-222 & Promotion of cellular migration and proliferation & {$[88-90]$} \\
miR-298 & Response to hypoxia and control of cell proliferation & {$[108]$} \\
miR-331 & Regulation cell proliferation, apoptosis, and inhibition of tumor invasion & {$[111]$} \\
miR-335 & Regulation of BRCA1 expression, inhibition of cellular proliferation and migra- & {$[109,110]$} \\
& tion & \\
miR-340 & Regulation cell proliferation and inhibition of tumor invasion & {$[176]$} \\
miR-495 & Promotion of cellular migration, proliferation, and response to hypoxia & {$[91]$} \\
\hline & &
\end{tabular}

\section{Preliminary panel of miRNA expression related to cervical cancer development}

Similarly to breast cancer, several miRNAs are associated with the inhibition of cellular proliferation and migration (as miR-10b, miR-32, miR-124, miR-138, miR-143, miR-146a, miR-192, miR-214, miR-328, miR-429, miR-466) [64, 116-125]. Other studies associated the expression of miR-15b, miR-17, miR-21, miR-124, miR-130a, miR-218, miR-409, miR-432, and miR-454 with the regulation of cell differentiation and development of cervical cancer [118, 119, 126-130]. Table 2 summarizes the top 20 main miRNAs and their cellular function implicated in the development of cervical cancer.

Several authors also evidenced the changes in the miRNA expression patterns in tissue samples and liquid biopsies, reinforcing the importance of studies using multiple types of samples. In this sense, Shukla et al. [118] observed that patients diagnosed with cervical cancer differentially expressed 119 miRNAs in tissue samples when compared to healthy controls, while 19 miRNAs were differentially expressed in serum and only 14 miRNAs were mutually altered in tissue and serum samples. A similar approach conducted by Nagy et al. [131] studying the miRNA expression in patients diagnosed with colorectal cancer identified that hsa-miR-3591-3p, hsa-miR-4506, hsa-miR-31, and hsamiR-187 are similarly altered in tissue and plasma samples.

\section{Preliminary panel of miRNA expression related to prostate cancer development}

Along the recent decade, several papers explored the miRNA expression from prostate cancer patients and compared these results with classical parameters (as PSA, 
Table 2 Preliminary panel for miRNA quantification related to cervical cancer development

\begin{tabular}{lll}
\hline miRNA & Cellular function & References \\
\hline miR-10b & Inhibition of cellular proliferation and invasion & {$[116,117]$} \\
miR-15b & Regulation of cellular proliferation and migration & {$[126]$} \\
miR-17 & Promotion of cellular proliferation and tumor angiogenesis & {$[118]$} \\
miR-21 & Promotion of cellular proliferation and tumor angiogenesis & {$[127]$} \\
miR-27b & Induction of cell proliferation, migration, and invasion & {$[177]$} \\
miR-32 & Inhibition of cellular proliferation and migration & {$[118]$} \\
miR-124 & Regulation of cellular differentiation and migration & {$[119]$} \\
miR-130a & Promotion of cellular proliferation and tumor angiogenesis & {$[128,129]$} \\
miR-138 & Inhibition of cellular proliferation and migration & {$[116]$} \\
miR-143 & Regulation of apoptotic mechanisms & {$[120]$} \\
miR-146a & Regulation of inflammatory responses and cell differentiation & {$[121]$} \\
miR-192 & Inhibition of cellular proliferation and migration & {$[64]$} \\
miR-214 & Inhibition of cellular proliferation & {$[44]$} \\
miR-218 & Regulation of cell differentiation and proliferation & {$[119]$} \\
miR-328 & Inhibition of cellular proliferation & {$[123]$} \\
miR-409 & Regulation of cellular proliferation and metastasis & {$[118]$} \\
miR-429 & Inhibition of cell proliferation, migration, and invasion & {$[124]$} \\
miR-432 & Regulation of cell proliferation and differentiation & {$[130]$} \\
miR-454 & Regulation of cellular proliferation and metastasis & {$[118]$} \\
miR-466 & Inhibition of cellular proliferation and control of apoptotic mechanisms & {$[125]$}
\end{tabular}

biopsies results, and Gleason score), associating the tissue-restricted or circulating miRNAs expression with the occurrence of tumoral cells and the prognosis [132-134].

In this sense, the expression of miR-17, miR-20a/miR-20b, miR-148, miR-650, and miR-4534 are associated with induction of cell differentiation and tumor angiogenesis [134-137]. On the other hand, the expression of let-7 family, miR-100, miR-124, miR125b, miR-132, miR-141, miR-143, miR-145, miR-195, miR-200a, miR-221, miR-296, miR-375, miR-382, and miR-449 are associated with the inhibition of cell proliferation and metastasis formation [94, 138-165]. Table 3 summarizes these findings associated in the development of prostate cancer. Figure 2 illustrates in a Venn diagram the sharing or differentially expressed miRNA profile in only one type of cancer, according to the data present in the tables. The star represents that, considering only these panels, there is no over position on miRNA expression mutually altered in all three cancer types according to the literature reviewed. However, this possibility was not excluded if we considered the expression of other miRNAs not presented in the tables.

\section{Current strategies adopted to quantify miRNAs and major challenges to the development of new diagnostic tools in the loT era}

Besides millions of deaths worldwide, the cancer diagnosis also has a huge economic impact on individuals and health systems. According to recent data from the National Cancer Institute- $\mathrm{NIH}$, the annual cost of treatment for breast, prostate, and cervical cancer is estimated at 35.6 billion dollars, mainly directed to hospitalizations, therapeutic agents, and palliative care. Additionally, the indirect impact associated with the lost 
Table 3 Preliminary panel for miRNA quantification related to prostate cancer development

\begin{tabular}{lll}
\hline miRNA & Cellular function & References \\
\hline let-7 family & Inhibition of cell proliferation, migration, and metastasis & {$[138-140]$} \\
miR-17 & Promotion of cellular proliferation and tumor angiogenesis & {$[134]$} \\
miR-20a/miR-20b & Regulation of cell proliferation, differentiation, and apoptosis & {$[134]$} \\
miR-100 & Inhibition of tumorigenesis, cell proliferation, and signaling & {$[141]$} \\
miR-124 & Inhibition of cellular proliferation and migration & {$[142,143]$} \\
miR-125b & Inhibition of cellular proliferation and induction of metastasis & {$[144,145]$} \\
miR-132 & Inhibition of cellular proliferation and signaling & {$[146]$} \\
miR-141 & Inhibition of cellular proliferation and migration & {$[94,147]$} \\
miR-143 & Regulation of apoptotic mechanisms & {$[148,149]$} \\
miR-145 & Inhibition of cellular proliferation, migration and tumor angiogenesis & {$[150,151]$} \\
miR-148 & Regulation of angiogenesis and apoptotic mechanisms & {$[135]$} \\
miR-195 & Inhibition of cellular proliferation, cell cycle progression, and metastasis & {$[152,153]$} \\
miR-200a & Inhibition of cellular proliferation and signaling & {$[154,155]$} \\
miR-221 & Inhibition of cell proliferation and invasion & {$[156-158]$} \\
miR-296 & Inhibition of cell proliferation and invasion; induction of apoptotic mecha- & {$[154,159,160]$} \\
& nisms & {$[161,162]$} \\
miR-375 & Inhibition of cell proliferation and invasion & {$[163]$} \\
miR-382 & Inhibition of cell proliferation, migration, and metastasis & {$[164,165]$} \\
miR-449 & Control of cell proliferation and differentiation & {$[136]$} \\
miR-650 & Regulation of pro-inflammatory signals and induction of cell proliferation & {$[137]$} \\
miR-4534 & Induction of cell migration and metastasis & \\
\hline & &
\end{tabular}

productivity associated with cancer diagnosis represents an extra amount of 17.2 billion dollars per year [166-168].

Among the main challenges to the dissemination of new tools for the accurate early cancer diagnosis are the use of expensive methods/equipment and the need for specialized professionals, which makes unfeasible their application in low- and middle-income countries and remote locations. The advances observed in cancer therapy changed the outcome and improved the quality of life during the treatment, evolving from a death sentence to a curable disease in several cases in only a few decades. However, despite the efforts, the diagnostic tests do not go along with these advances or are expensive to be applied as screening methods in primary health care $[92,93]$.

Usually, the cancer diagnostic methods are based on high-resolution imaging, detection of metabolites in tissue samples/biological fluids, or morphological/phenotypic cellular analysis. Nevertheless, even when all those requirements are available, it does not guarantee the establishment of a precise early cancer diagnosis due to the stage of disease development, lack of sensibility or misinterpretation of requested exams, and falsepositive or false-negative results [10].

In recent decades, the initial techniques to detect miRNAs were optimized and progressively replaced by more accurate and less laborious methods [94]. Currently, the main techniques used for miRNA quantification are based on microarray platforms, qPCR, next-generation sequencing, Northern blotting, or isothermal amplification. Among these methods, those based on microarray platforms and qPCR are widely used in basic researches and manufactured by different companies. In general, both strategies 
(1) Breast cancer

(2) Cervical cancer

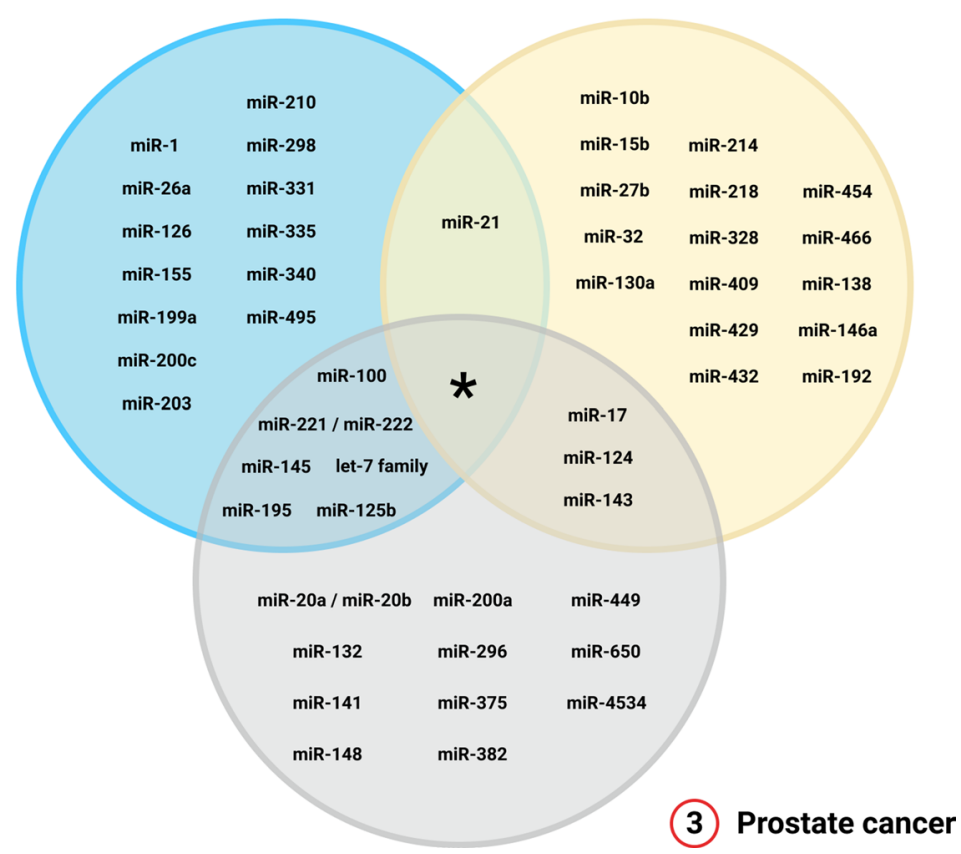

Fig. 2 Representation in a Venn diagram of the sharing or differentially expressed miRNA profile in only one type, according to the proposed panels for (1) breast; (2) cervical; or (3) prostate cancer. The star represents the absence of over position on miRNA profile mutually altered in all three cancer types according to the literature reviewed. This possibility, however, was not excluded if we consider the expression of other miRNAs not presented in the tables

adopt a labeled-probe strategy to quantify their targets using optical sensors and report the results. However, the elevated operational cost of analysis and the multiple-step processing samples are issues that need to be solved to allow the scalability of these methods using clinical samples.

On the other hand, the application of next-generation sequencing, Northern blot, and isothermal amplification for miRNA quantification requires multiple-step protocols and they are more expensive than microarray platforms and qPCR, especially when we analyze multiple targets simultaneously. Table 4 summarizes the main features of each method and current limitations for their application as a screening method for early cancer detection. Considering these features, recent papers that quantify miRNAs in clinical samples aiming to detect potential biomarkers are mostly based on microarrays platforms and qPCRs strategies, regarding their better processing scalability, analysis of results, and overall costs in multiple targets assays [80, 92, 93, 101].

In this sense, one of the major challenges on miRNA field is to apply the knowledge from different areas (as medicine and biomedical engineering) to the development of a trusted, cheap and portable platform/devices, which uses minimally invasive samples (i.e., serum/plasma, saliva or urine) to contribute for early cancer detection. However, beyond the inherent biological aspects, the development of these new tools should also consider their application as a smart device and be able to connect with other medical devices and to the Internet of Things (IoT). An efficient low-cost platform using 


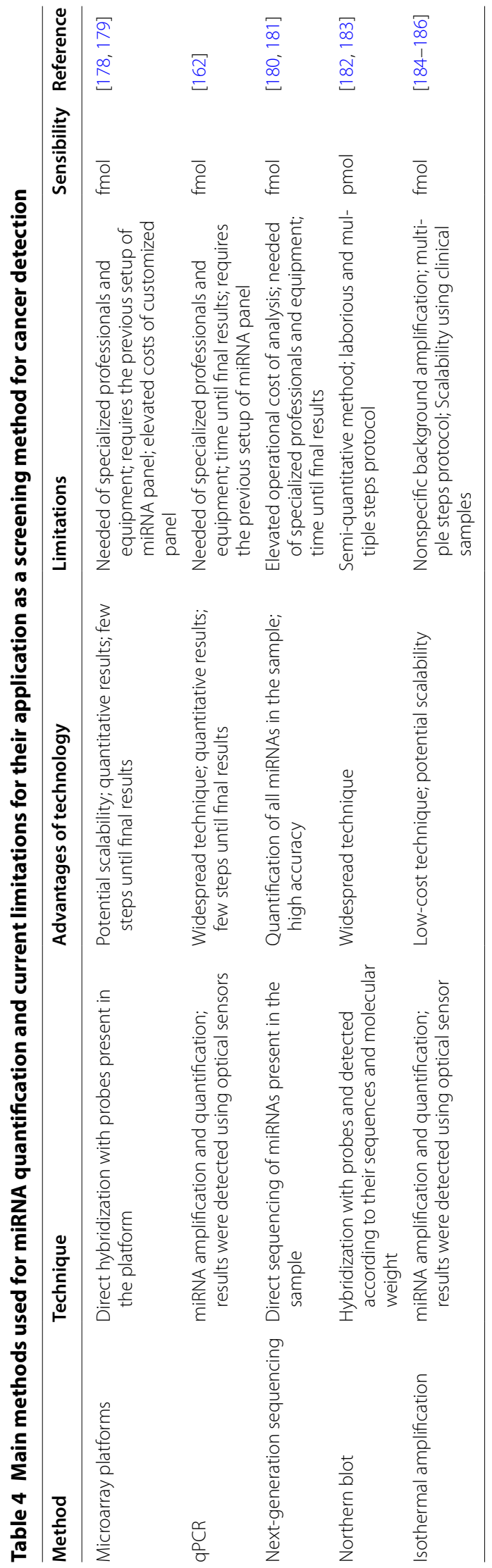




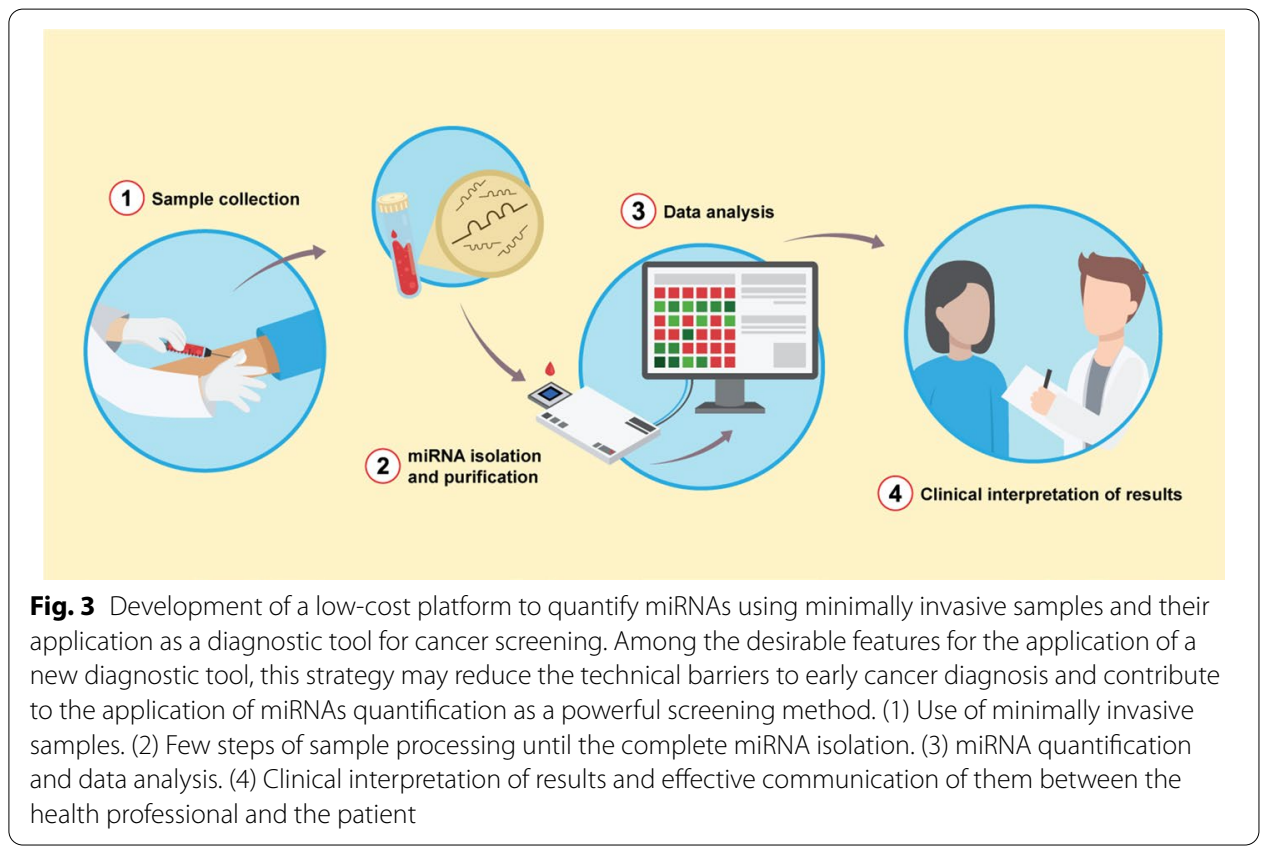

minimally invasive samples, as represented in Fig. 3, which with few steps since the minimally invasive sample collection (step 1), sampling processing (step 2), miRNA quantification (step 3) through the final communication of results (step 4) can reduce these technical barriers and contribute to the democratization of access to cancer screening tests, even in remote populations. The elaboration of a complex panel based on updated results from several platforms and the device connection with specialized centers could be useful to test isolated populations and optimize the analysis of results, contributing to developing personalized medicine strategies and translating the knowledge from bench to save lives.

Taken together, these advances may represent a new era in cancer diagnosis procedures. As observed in several industry segments, the revolution 4.0 in health practices and devices can subvert the rationale of investments (from hospitalization to primary care assistance), contributing to early diagnosis and optimizing the resources available $[95,169,170]$.

\section{Conclusion}

Considering the progressive number of new cancer cases every year worldwide, the development of new tools to improve the early detection methods is critical to improving the sensitivity and specificity in screening tests to allow a better prognosis for these patients. Besides the deaths associated with late diagnosis, cancer therapy has a huge economic impact associated with therapies, prolonged hospitalization periods, and the occurrence of metastasis. Currently, several papers associated changes in the miRNA expression to the development of tissue-specific modifications and aberrant cellular proliferation. Although there is a lack in the consensus on the miRNA expression between tissue and biological fluid samples, the development of new studies and the establishment of an adequate biomarkers panel may be useful to detect several cancer types using 
minimally invasive samples. The current methods used to quantify miRNAs in clinical samples frequently are expensive, based on multiple steps protocols and demand a highspecialized professionals, making their large-scale application unfeasible.

In this sense, the application of miRNAs as biomarkers of early cancer development may contribute to the development of precision medicine and improve life expectancy and quality of life from affected patients. However, there is still a challenge to make the miRNA quantification an economically feasible approach to be adopted widely in primary health care. The development of new technologies and/or optimization of current strategies adopted to quantify these molecules applied into a new portable device able to detect these molecules using blood or other biological fluids could represent an important strategy to democratize, with agility and excellence, the cancer screening strategy and take the next step forward to the development of personalized medicine.

\section{Abbreviations}

BCl-2: B-cell lymphoma 2 protein; CD8+T cells: Cytotoxic lymphocyte; CNS: Central nervous system; dsRNA: Doublestrand RNA; ER-a/ $\beta$ : Estrogen receptor-alpha/beta; FFPE: Formalin-fixed paraffin-embedded; loT: Internet of things; mRNAs: Messenger RNAs; miRNAs: MicroRNAs; miR-RISC: MicroRNA-induced silencing complex; NIH: National Institutes of Health; NK cells: Natural killer cells; nt: Nucleotides; onco-miRs: Oncogenic miRNAs; p53: Cellular protein 53; PSA: Prostate-specific antigen; PTEN: Phosphatase and tensin homolog protein; qPCR: Quantitative polymerase chain reaction; RNA: Ribonucleic acid; RECK: Reversion-inducing cysteine-rich protein with Kazal motifs; Treg cells: Regulatory T cells.

\section{Acknowledgements}

The authors are grateful to Roberto Lima and Yasmim Morais for the illustrations present in this paper.

\section{Authors' contributions}

LGJL and AHFM designed the review. LJGL wrote the paper. AHFM, RAMV, and EJSSB reviewed and added new data to the manuscript. All authors read and approved the final manuscript.

\section{Funding}

The funding for this work was provided by the Brazilian Ministry of Health (TED no. 158/2017).

Availability of supporting data

All data generated or analyzed during this study are included in this published article.

Ethics approval and consent to participate

Not applicable.

\section{Consent for publication}

Not applicable.

\section{Competing interests}

The authors declare that they have no competing interests.

\section{Author details}

${ }^{1}$ Advanced Nucleus of Technological Innovation (NAVI), Federal Institute of Rio Grande do Norte (IFRN), Avenue Senador Salgado Filho 1559, Natal, RN 59015-000, Brazil. ${ }^{2}$ Laboratory of Technological Innovation in Health (LAIS), Hospital Universitário Onofre Lopes (HUOL), Federal University of Rio Grande do Norte (UFRN), Campus Lagoa Nova, Natal, RN, Brazil. ${ }^{3}$ Division of Oncology and Hematology, Hospital Universitário Onofre Lopes (HUOL), Federal University of Rio Grande do Norte (UFRN), Campus Lagoa Nova, Natal, RN, Brazil.

Received: 31 October 2020 Accepted: 5 February 2021

Published online: 16 February 2021

\section{References}

1. Wahid F, Shehzad A, Khan T, Kim YY. MicroRNAs: synthesis, mechanism, function, and recent clinical trials. Biochim Biophys Acta. 2010. https://doi.org/10.1016/j.bbamcr.2010.06.013.

2. Chen $R$, Jiang $N$, Jiang $Q$, Sun $X$, Wang $Y$, Zhang $H$, Hu Z. Exploring microRNA-like small RNAs in the filamentous fungus Fusarium oxysporum. PLoS ONE. 2014. https://doi.org/10.1371/journal.pone.0104956.

3. Lee RC, Feinbaum RL, Ambros V. The C elegans heterochronic gene lin-4 encodes small RNAs with antisense complementarity to lin-14. Cell. 1993. https://doi.org/10.1016/0092-8674(93)90529-Y.

4. Alvarez-Garcia I, Miska EA. MicroRNA functions in animal development and human disease. Development. 2005 https://doi.org/10.1242/dev.02073. 
5. Kozomara A, Griffiths-Jones S. MiRBase: Annotating high confidence microRNAs using deep sequencing data. Nucleic Acids Res. 2014. https://doi.org/10.1093/nar/gkt1181.

6. Kozomara A, Birgaoanu M, Griffiths-Jones S. MiRBase: From microRNA sequences to function. Nucleic Acids Res. 2019. https://doi.org/10.1093/nar/gky1141.

7. Cai Y, Yu X, Hu S, Yu J. A Brief Review on the Mechanisms of miRNA Regulation. Genomics Proteomics Bioinform. 2009. https://doi.org/10.1016/S1672-0229(08)60044-3.

8. Oyama Y, Bartman CM, Gile J, Eckle T. Circadian microRNAs in cardioprotection. Curr Pharm Design. 2017. https:// doi.org/10.2174/1381612823666170707165319.

9. Chen W, Liu Z, Li T, Zhang R, Xue Y, Zhong Y, Bai W, Zhou D, Zhao Z. Regulation of Drosophila circadian rhythms by miRNA let-7 is mediated by a regulatory cycle. Nat Commun. 2014. https://doi.org/10.1038/ncomms6549.

10. Magri F, Vanoli F, Corti S. miRNA in spinal muscular atrophy pathogenesis and therapy. J Sel Mol Med. 2018. https ://doi.org/10.1016/j.bbamcr.2010.06.013.

11. Ma Y. The Challenge of microRNA as a Biomarker of Epilepsy. Curr Neuropharmacol. 2017. https://doi. org/10.2174/1570159x15666170703102410.

12. Xue L, Wang Y, Yue S, Zhang J. The expression of miRNA-221 and miRNA-222 in gliomas patients and their prognosis. Neurol Sci. 2017. https://doi.org/10.1007/s10072-016-2710-y.

13. Wojciechowska A, Braniewska A, Kozar-Kamińska K. MicroRNA in cardiovascular biology and disease. Adv Clin Exp Med. 2017. https://doi.org/10.17219/acem/62915.

14. Biswas S, Haleyurgirisetty M, Lee S, Hewlett I, Devadas K. Development and validation of plasma miRNA biomarker signature panel for the detection of early HIV-1 infection. EBioMedicine. 2019. https://doi.org/10.1016/j.ebiom .2019.04.023.

15. Backes C, Meese E, Keller A. Specific miRNA disease biomarkers in blood, serum and plasma: challenges and prospects. Mol Diagn Therapy. 2016. https://doi.org/10.1007/s40291-016-0221-4.

16. Izzotti A, Carozzo S, Pulliero A, Zhabayeva D, Ravetti JL, Bersimbaev R. Extracellular MicroRNA in liquid biopsy: applicability in cancer diagnosis and prevention. Am J Cancer Res. 2016;6(7):1461-93.

17. Shigeyasu K, Toden S, Zumwalt TJ, Okugawa Y, Goel A. Emerging role of microRNAs as liquid biopsy biomarkers in gastrointestinal cancers. Clin Cancer Res. 2017. https://doi.org/10.1158/1078-0432.CCR-16-1676.

18. Faruq O, Vecchione A. microRNA: Diagnostic perspective. Front Med. 2015. https://doi.org/10.3389/ fmed.2015.00051.

19. Weber JA, Baxter DH, Zhang S, Huang DY, Huang KH, Lee MJ, Galas DJ, Wang K. The microRNA spectrum in 12 body fluids. Clin Chem. 2010. https://doi.org/10.1373/clinchem.2010.147405.

20. Cheerla N, Gevaert O. MicroRNA based pan-cancer diagnosis and treatment recommendation. BMC Bioinform. 2017. https://doi.org/10.1186/s12859-016-1421-y.

21. World Health Organization. Cancer Today. 2018. https://doi.org/10.1371/journal.pone.0104956.

22. INCA: INCA. Estimativa 2020 : incidência de câncer no Brasil. Technical report, INCA; 2019.

23. Dong H, Luo L, Hong S, Siu H, Xiao Y, Jin L, Chen R, Xiong M. Integrated analysis of mutations, miRNA and mRNA expression in glioblastoma. BMC Syst Biol. 2010. https://doi.org/10.1186/1752-0509-4-163.

24. Bayraktar R, Van Roosbroeck K, Calin GA. Cell-to-cell communication: microRNAs as hormones. Mol Oncol. 2017. https://doi.org/10.1002/1878-0261.12144.

25. Toms D, Pan B, Li J. Endocrine regulation in the ovary by MicroRNA during the estrous cycle. Front Electrol. 2018. https://doi.org/10.3389/fendo.2017.00378.

26. Olejniczak M, Kotowska-Zimmer A, KrzyzosiakW. Stress-induced changes in miRNA biogenesis and functioning. Cell Mol Life Sci. 2018. https://doi.org/10.1007/s00018-017-2591-0.

27. Iorio MV, Croce CM. MicroRNA dysregulation in cancer: diagnostics, monitoring and therapeutics. A comprehensive review. EMBO Mol Med. 2012. https://doi.org/10.1002/emmm.201100209.

28. Turchinovich A, Weiz L, Langheinz A, Burwinkel B. Characterization of extracellular circulating microRNA. Nucleic Acids Res. 2011. https://doi.org/10.1093/nar/gkr254.

29. Chen $X$, Liang $H$, Zhang J, Zen $K$, Zhang CY. Secreted microRNAs: a new form of intercellular communication. Trens Cell Biol. 2012. https://doi.org/10.1016/j.tcb.2011.12.001.

30. O'Brien J, Hayder H, Zayed Y, Peng C. Overview of microRNA biogenesis, mechanisms of actions, and circulation. Front Endocrinol (Lausanne). 2018. https://doi.org/10.3389/fendo.2018.00402.

31. Ludwig N, Leidinger P, Becker K, Backes C, Fehlmann T, Pallasch C, Rheinheimer S, Meder B, Stähler C, Meese E, Keller A. Distribution of miRNA expression across human tissues. Nucleic Acids Res. 2016. https://doi.org/10.1093/nar/ gkw116.

32. Ying W, Riopel M, Bandyopadhyay G, Dong Y, Birmingham A, Seo JB, Ofrecio JM, Wollam J, Hernandez-Carretero A, Fu W, Li P, Olefsky JM. Adipose Tissue Macrophage-Derived Exosomal miRNAs Can Modulate in Vivo and in Vitro Insulin Sensitivity. Cell. 2017. https://doi.org/10.1016/j.cell.2017.08.035.

33. Vrtačnik P, Ostanek B, Mencej-Bedrač S, Marc J. The many faces of estrogen signaling. Biochem Med. 2014. https:// doi.org/10.11613/BM.2014.035.

34. Shah MY, Ferrajoli A, Sood AK, Lopez-Berestein G, Calin GA. microRNA Therapeutics in Cancer - An Emerging Concept. EBioMedicine. 2016. https://doi.org/10.1016/j.ebiom.2016.09.017.

35. Chakraborty C, Sharma AR, Sharma G, Doss CGP, Lee SS. Therapeutic miRNA and siRNA: Moving from Bench to Clinic as Next Generation Medicine. Mol Ther Nucleic Acids. 2017. https://doi.org/10.1016/j.omtn.2017.06.005.

36. Baumann V, Winkler J. MiRNA-based therapies: strategies and delivery platforms for oligonucleotide and nonoligonucleotide agents. Future Med Chem. 2014. https://doi.org/10.4155/fmc.14.116.

37. Yang N, Zhu S, Lv X, Qiao Y, Liu YJ, Chen J. MicroRNAs: Pleiotropic regulators in the tumor microenvironment. Front Immunol. 2018. https://doi.org/10.3389/fimmu.2018.02491.

38. Curtale G. MiRNAs at the Crossroads between Innate Immunity and Cancer: Focus on Macrophages. Cells. 2018. https://doi.org/10.3390/cells7020012.

39. Bray F, Jemal A, Grey N, Ferlay J, Forman D. Global cancer transitions according to the Human Development Index (2008-2030): A population-based study. Lancet Oncol. 2012. https://doi.org/10.1016/S1470-2045(12)70211-5. 
40. Yang HY, Barbi J, Wu CY, Zheng Y, Vignali PDA, Wu X, Tao JH, Park BV, Bandara S, Novack L, Ni X, Yang X, Chang KY, Wu RC, Zhang J, Yang CW, Pardoll DM, Li H, Pan F. MicroRNA-17 Modulates Regulatory T Cell Function by Targeting Co-regulators of the Foxp3 Transcription Factor. Immunity. 2016. https://doi.org/10.1016/0092-8674(93)90529-Y.

41. Hippen KL, Loschi M, Nicholls J, MacDonald KPA, Blazar BR. Effects of MicroRNA on regulatory T Cells and implications for adoptive cellular therapy to ameliorate graft-versus-host disease. Front Immunol. 2018. https://doi. org/10.3389/fimmu.2017.02014.

42. Squadrito ML, Etzrodt M, De Palma M, Pittet MJ. MicroRNA-mediated control of macrophages and its implications for cancer. Trends Immunol. 2013. https://doi.org/10.1016/j.it.2013.02.003.

43. Kong YW, Ferland-McCollough D, Jackson TJ, Bushell M. MicroRNAs in cancer management. Lancet Oncol. 2012. https://doi.org/10.1016/S1470-2045(12)70073-6.

44. Yang Y, Chaerkady R, Beer MA, Mendell JT, Pandey A. Identification of miR-21 targets in breast cancer cells using a quantitative proteomic approach. Proteomics. 2009. https://doi.org/10.1002/pmic.200800551.

45. Feng YH, Tsao CJ. Emerging role of microRNA-21 in cancer. Review. 2016. https://doi.org/10.3892/br.2016.747.

46. Wang H, Tan Z, Hu H, Liu H, Wu T, Zheng C, Wang X, Luo Z, Wang J, Liu S, Lu Z, Tu J. MicroRNA-21 promotes breast cancer proliferation and metastasis by targeting LZTFL1. BMC Cancer. 2019. https://doi.org/10.1242/dev.02073.

47. Xu LF, Wu ZP, Chen Y, Zhu QS, Hamidi S, Navab R. MicroRNA-21 (miR-21) regulates cellular proliferation, invasion, migration, and apoptosis by targeting PTEN, RECK and BCl-2 in lung squamous carcinoma, Gejiu City, China. PLoS ONE. 2014. https://doi.org/10.1242/dev.02073.

48. Li P, XU T, Zhou X, Liao L, Pang G, Luo W, Han L, Zhang J, Luo X, Xie X, Zhu K. Downregulation of miRNA-141 in breast cancer cells is associated with cell migration and invasion: involvement of ANP32E targeting. Cancer Med. 2017. https://doi.org/10.1242/dev.02073.

49. Long ZH, Bai ZG, Song JN, Zheng Z, Li J, Zhang J, Cai J, Yao HW, Wang J, Yang YC, Yin J, Zhang ZT. MiR-141 inhibits proliferation and migration of colorectal cancer sw480 cells. Anticancer Res. 2017. https://doi.org/10.1242/ dev.02073.

50. Huang S, Wa Q, Pan J, Peng X, Ren D, Huang Y, Chen X, Tang Y. Downregulation of miR-141-3p promotes bone metastasis via activating NF- $\kappa$ B signaling in prostate cancer. J Exp Clin Cancer Res. 2017. https://doi.org/10.1242/ dev.02073.

51. Liu J, Zhang C, Zhao Y, Feng Z. MicroRNA Control of p53. J Cell Biochem. 2017. https://doi.org/10.1002/jcb.25609.

52. Goeman F, Strano S, Blandino G. MicroRNAs as Key Effectors in the p53 Network. Int Rev Cell Mol Biol. 2017. https ://doi.org/10.1093/nar/gkt1181.

53. Luo Z, Cui R, Tili E, Croce C. Friend or Foe: MicroRNAs in the p53 network. Cancer Lett. 2018. https://doi. org/10.1093/nar/gkt1181.

54. Niazi S, Purohit M, Niazi JH. Role of p53 circuitry in tumorigenesis: A brief review. Eur Med Chem. 2018. https://doi. org/10.1093/nar/gkt1181.

55. Shenouda SK, Alahari SK. MicroRNA function in cancer: Oncogene or a tumor suppressor? Cancer Metastasis Rev. 2009. https://doi.org/10.1093/nar/gkt1181.

56. Suzuki HI, Yamagata K, Sugimoto K, Iwamoto T, Kato S, Miyazono K. Modulation of microRNA processing by p53. Nature. 2009. https://doi.org/10.1093/nar/gkt1181.

57. Feng Z, Zhang C, Wu R, Hu W. Tumor suppressor p53 meets microRNAs. J Mol Cell Biol. 2011. https://doi. org/10.1093/nar/gkt1181.

58. Hamam R, Hamam D, Alsaleh KA, Kassem M, Zaher W, Alfayez M, Aldahmash A, Alajez NM. Circulating microRNAs in breast cancer: novel diagnostic and prognostic biomarkers. Cell Death Dis. 2017. https://doi.org/10.1093/nar/ gkt1181.

59. Mognato M, Celotti L. MicroRNAs Used in Combination with Anti-Cancer Treatments Can Enhance Therapy Efficacy. Mini-Rev Med Chem. 2015. https://doi.org/10.1093/nar/gkt1181.

60. Petrovic N, Ergun S. miRNAs as Potential Treatment Targets and Treatment Options in Cancer. Mol Diagn Ther. 2018. https://doi.org/10.1093/nar/gkt1181.

61. Si W, Shen J, Zheng $\mathrm{H}$, Fan W. The role and mechanisms of action of microRNAs in cancer drug resistance. Review. 2019. https://doi.org/10.1186/s13148-018-0587-8.

62. Chuang JC, Jones PA. Epigenetics and microRNAs. Pediatr Res. 2007. https://doi.org/10.1093/nar/gky1141.

63. Wang H, Peng R, Wang J, Qin Z, Xue L. Circulating microRNAs as potential cancer biomarkers: the advantage and disadvantage. Clin Epigenet. 2018. https://doi.org/10.1093/nar/gky1141.

64. Farzanehpour M, Mozhgani SH, Jalilvand S, Faghihloo E, Akhavan S, Salimi V, Azad TM. Serum and tissue miRNAs: Potential biomarkers for the diagnosis of cervical cancer. Virol J. 2019. https://doi.org/10.1093/nar/gky1141.

65. Heneghan HM, Miller N, Lowery AJ, Sweeney KJ, Kerin MJ. MicroRNAs as Novel Biomarkers for Breast Cancer. J Oncol. 2010. https://doi.org/10.1093/nar/gky1141.

66. Qadir MI, Faheem A. miRNA: a diagnostic and therapeutic tool for pancreatic cancer. Crit Rev Eukaryotic Gene Express. 2017. https://doi.org/10.1093/nar/gky1141.

67. Li X, Kleeman S, Coburn SB, Fumagalli C, Perner J, Jammula S, Pfeiffer RM, Orzolek L, Hao H, Taylor PR, Miremad A, Galeano-Dalmau N, Lao-Sirieix P, Tennyson M, MacRae S, Cook MB, Fitzgerald RC. Selection and Application of Tissue microRNAs for Nonendoscopic Diagnosis of Barrett's Esophagus. Gastroenterology. 2018. https://doi. org/10.1093/nar/gky1141.

68. Hanna J, Hossain GS, Kocerha J. The potential for microRNA therapeutics and clinical research. Front Genet. 2019. https://doi.org/10.1093/nar/gky1141.

69. Lu J, Getz G, Miska EA, Alvarez-Saavedra E, Lamb J, Peck D, Sweet-Cordero A, Ebert BL, Mak RH, Ferrando AA, Downing JR, Jacks T, Horvitz HR, Golub TR. MicroRNA expression profiles classify human cancers. Nature. 2005. https://doi.org/10.1093/nar/gky1141.

70. Rosenfeld N, Aharonov R, Meiri E, Rosenwald S, Spector Y, Zepeniuk M, Benjamin H, Shabes N, Tabak S, Levy A, Lebanony D, Goren Y, Silberschein E, Targan N, Ben-Ari A, Gilad S, Sion-Vardy N, Tobar A, Feinmesser M, Kharenko O, Nativ O, Nass D, Perelman M, Yosepovich A, Shalmon B, Polak-Charcon S, Fridman E, Avniel A, Bentwich I, Bentwich 
Z, Cohen D, Chajut A, Barshack I. MicroRNAs accurately identify cancer tissue origin. Nat Biotechnol. 2008. https:// doi.org/10.1093/nar/gky1141.

71. Paranjape T, Slack FJ, Weidhaas JB. MicroRNAs: Tools for cancer diagnostics. Gut. 2009. https://doi.org/10.1136/ gut.2009.179531.

72. Sun Y, Guo W, Wang F, Peng F, Yang Y, Dai X, Liu X, Bai Z. Transcriptome and multivariable data analysis of Corynebacterium glutamicum under different dissolved oxygen conditions in bioreactors. PLoS ONE. 2016. https ://doi.org/10.1016/S1672-0229(08)60044-3.

73. Frères P, Wenric S, Boukerroucha M, Fasquelle C, Thiry J, Bovy N, Struman I, Geurts P, Collignon J, Schroeder H, Kridelka F, Lifrange E, Jossa V, Bours V, Josse C, Jerusalem G. Circulating microRNA-based screening tool for breast cancer. Oncotarget. 2016. https://doi.org/10.1016/S1672-0229(08)60044-3.

74. Calin GA, Ferracin M, Cimmino A, Di Leva G, Shimizu M, Wojcik SE, lorio MV, Visone R, Sever NI, Fabbri M, luliano R, Palumbo T, Pichiorri F, Roldo C, Garzon R, Sevignani C, Rassenti L, Alder H, Volinia S, Liu CG, Kipps TJ, Negrini M, Croce CM. A microRNA signature associated with prognosis and progression in chronic lymphocytic leukemia. N Engl J Med. 2005. https://doi.org/10.1016/S1672-0229(08)60044-3.

75. Hironaka-Mitsuhashi A, Matsuzaki J, Takahashi RU, Yoshida M, Nezu Y, Yamamoto Y, Shiino S, Kinoshita T, Ushijima T, Hiraoka N, Shimizu C, Tamura K, Ochiya T. A tissue microRNA signature that predicts the prognosis of breast cancer in young women. PLoS ONE. 2017. https://doi.org/10.1016/S1672-0229(08)60044-3.

76. Peskoe SB, Barber JR, Zheng Q, Meeker AK, De Marzo AM, Platz EA, Lupold SE. Differential long-term stability of microRNAs and RNU6B snRNA in 12-20 year old archived formalin-fixed paraffin-embedded specimens. BMC Cancer. 2017. https://doi.org/10.1016/S1672-0229(08)60044-3.

77. Du L, Pertsemlidis A. Cancer and neurodegenerative disorders: Pathogenic convergence through microRNA regulation. J Mol Cell Biol. 2011. https://doi.org/10.1016/S1672-0229(08)60044-3.

78. Saito Y, Saito H. MicroRNAs in cancers and neurodegenerative disorders. Front Genet. 2012. https://doi. org/10.1016/S1672-0229(08)60044-3.

79. Godlewski J, Lenart J, Salinska E. MicroRNA in brain pathology: neurodegeneration the other side of the brain cancer. Noncoding RNA. 2019. https://doi.org/10.1016/S1672-0229(08)60044-3.

80. Asano N, Matsuzaki J, Ichikawa M, Kawauchi J, Takizawa S, Aoki Y, Sakamoto H, Yoshida A, Kobayashi E, Tanzawa Y, Nakayama R, Morioka H, Matsumoto M, Nakamura M, Kondo T, Kato K, Tsuchiya N, Kawai A, Ochiya T. A serum microRNA classifier for the diagnosis of sarcomas of various histological subtypes. Nat Commun. 2019. https://doi. org/10.1016/S1672-0229(08)60044-3.

81. Søkilde R, Persson H, Ehinger A, Pirona AC, Fernö M, Hegardt C, Larsson C, Loman N, Malmberg M, Rydén L, Saal L, Borg $\AA$, Vallon-Christerson J, Rovira C. Refinement of breast cancer molecular classification by miRNA expression profiles. BMC Genomics. 2019. https://doi.org/10.1186/s12864-019-5887-7.

82. Lopez-Rincon A, Martinez-Archundia M, Martinez-Ruiz GU, Schoenhuth A, Tonda A. Automatic discovery of 100-miRNA signature for cancer classification using ensemble feature selection. BMC Bioinform. 2019. https://doi. org/10.2174/1381612823666170707165319.

83. Iorio MV, Ferracin M, Liu CG, Veronese A, Spizzo R, Sabbioni S, Magri E, Pedriali M, Fabbri M, Campiglio M, Ménard S, Palazzo JP, Rosenberg A, Musiani P, Volinia S, Nenci I, Calin GA, Querzoli P, Negrini M, Croce CM. MicroRNA gene expression deregulation in human breast cancer. Cancer Res. 2005. https://doi.org/10.2174/138161282366617 0707165319.

84. Li P, Guo Y, Bledsoe G, Yang Z, Chao L, Chao J. Kallistatin induces breast cancer cell apoptosis and autophagy by modulating Wnt signaling and microRNA synthesis. Exp Cell Res. 2016. https://doi.org/10.2174/138161282366617 0707165319.

85. Liu J, Li X, Wang M, Xiao G, Yang G, Wang H, Li Y, Sun X, Qin S, Du N, Ren H, Pang Y. A miR-26a/E2F7 feedback loop contributes to tamoxifen resistance in ER-positive breast cancer. Int J Oncol. 2018. https://doi.org/10.2174/13816 12823666170707165319.

86. Tormo E, Adam-Artigues A, Ballester S, Pineda B, Zazo S, González-Alonso P, Albanell J, Rovira A, Rojo F, Lluch A, Eroles P. The role of miR-26a and miR-30b in HER2 + breast cancer trastuzumab resistance and regulation of the CCNE2 gene. Scientific Rep. 2017. https://doi.org/10.2174/1381612823666170707165319.

87. Dinami R, Ercolani C, Petti E, Piazza S, Ciani Y, Sestito R, Sacconi A, Biagioni F, Le Sage C, Agami R, Benetti R, Mottolese M, Schneider C, Blandino G, Schoeftner S. miR-155 drives telomere fragility in human breast cancer by targeting TRF1. Cancer Res. 2014. https://doi.org/10.2174/1381612823666170707165319.

88. Rao X, Di Leva G, Li M, Fang F, Devlin C, Hartman-Frey C, Burow ME, Ivan M, Croce CM, Nephew KP. MicroRNA-221/222 confers breast cancer fulvestrant resistance by regulating multiple signaling pathways. Oncogene. 2011. https://doi.org/10.2174/1381612823666170707165319.

89. Miller TE, Ghoshal K, Ramaswamy B, Roy S, Datta J, Shapiro CL, Jacob S, Majumder S. MicroRNA-221/222 confers tamoxifen resistance in breast cancer by targeting p27Kip1. J Biol Chem. 2008. https://doi.org/10.2174/13816 12823666170707165319.

90. Zhao JJ, Lin J, Yang H, Kong W, He L, Ma X, Coppola D, Cheng JQ. MicroRNA-221/222 negatively regulates estrogen receptor $\alpha$ and is associated with tamoxifen resistance in breast cancer. J Biol Chem. 2008. https://doi. org/10.2174/1381612823666170707165319.

91. Mishra S, Srivastava AK, Suman S, Kumar V, Shukla Y. Circulating miRNAs revealed as surrogate molecular signatures for the early detection of breast cancer. Cancer Lett. 2015. https://doi.org/10.1016/j.canlet.2015.07.045.

92. Moody L, He H, Pan YX, Chen H. Methods and novel technology for microRNA quantification in colorectal cancer screening. Clin Epigent. 2017. https://doi.org/10.1038/ncomms6549.

93. Garcia-Elias A, Alloza L, Puigdecanet E, Nonell L, Tajes M, Curado J, Enjuanes C, Díaz O, Bruguera J, Martí-Almor J, Comín-Colet J, Benito B. Defining quantification methods and optimizing protocols for microarray hybridization of circulating microRNAs. Scientific Rep. 2017. https://doi.org/10.1038/ncomms6549.

94. Mitchell PS, Parkin RK, Kroh EM, Fritz BR, Wyman SK, Pogosova-Agadjanyan EL, Peterson A, Noteboom J, O'Briant KC, Allen A, Lin DW, Urban N, Drescher CW, Knudsen BS, Stirewalt DL, Gentleman R, Vessella RL, Nelson PS, Martin 
DB, Tewari M. Circulating microRNAs as stable blood-based markers for cancer detection. Proc Natl Acad Sci USA. 2008. https://doi.org/10.1038/ncomms6549.

95. Gelband H, Sankaranarayanan R, Gauvreau CL, Horton S, Anderson BO, Bray F, Cleary J, Dare AJ, Denny L, Gospodarowicz MK, Gupta S, Howard SC, Jaffray DA, Knaul F, Levin C, Rabeneck L, Rajaraman P, Sullivan T, Trimble EL, Jha P. Costs, affordability, and feasibility of an essential package of cancer control interventions in low-income and middle-income countries: Key messages from Disease Control Priorities, 3rd edition. 2016. https://doi.org/10.1016/ S0140-6736(15)00755-2

96. Xiao Y, Watson M. Guidance on conducting a systematic literature review. J Plan Educ Res. 2019;39(1):93-112.

97. Liu C, Zhang S, Wang Q, Zhang X. Tumor suppressor miR-1 inhibits tumor growth and metastasis by simultaneously targeting multiple genes. Oncotarget. 2017. https://doi.org/10.1038/ncomms6549.

98. Gong $Y$, He T, Yang L, Yang G, Chen Y, Zhang X. The role of miR-100 in regulating apoptosis of breast cancer cells. Scientific Rep. 2015. https://doi.org/10.1038/ncomms6549.

99. Pakravan K, Babashah S, Sadeghizadeh M, Mowla SJ, Mossahebi-Mohammadi M, Ataei F, Dana N, Javan M. MicroRNA-100 shuttled by mesenchymal stem cell-derived exosomes suppresses in vitro angiogenesis through modulating the mTOR/HIF-1 $\alpha$ NEGF signaling axis in breast cancer cells. Cell Oncol. 2017. https://doi.org/10.1038/ ncomms6549.

100. Akhavantabasi S, Sapmaz A, Tuna S, Erson-Bensan AE. MiR-125b targets ARID3B in breast cancer cells. Cell Struct Funct. 2012. https://doi.org/10.1038/ncomms6549.

101. Chen Y, Gelfond JA, MCManus LM, Shireman PK. Reproducibility of quantitative rt-pcr array in mirna expression profiling and comparison with microarray analysis. BMC Genomics. 2009;10(1):1-10.

102. Chen J, Tian W, Cai H, He H, Deng Y. Down-regulation of microRNA-200C is associated with drug resistance in human breast cancer. Med Oncol. 2012. https://doi.org/10.1038/ncomms6549.

103. Wang CZ, Yuan P, Li Y. miR-126 regulated breast cancer cell invasion by targeting ADAM9. Int I Clin Exp Pathol. 2015;8(6):6547-53.

104. Alhasan L. MiR-126 modulates angiogenesis in breast cancer by targeting VEGF-A -mRNA. Asian Pac J Cancer Prev. 2019. https://doi.org/10.1038/ncomms6549.

105. Zou C, Xu Q, Mao F, Li D, Bian C, Liu LZ, Jiang Y, Chen X, Qi Y, Zhang X, Wang X, Sun Q, Kung HF, Lin MC, Dress A, Wardle F, Jiang BH, Lai L. MiR-145 inhibits tumor angiogenesis and growth by N-RAS and VEGF. Cell Cycle. 2012. https://doi.org/10.4161/cc.20598.

106. Zheng M, Sun X, Li Y, Zuo W. MicroRNA-145 inhibits growth and migration of breast cancer cells through targeting oncoprotein ROCK1. Tumor Biol. 2016. https://doi.org/10.1016/j.bbamcr.2010.06.013.

107. Costales MG, Haga CL, Velagapudi SP, Childs-Disney JL, Phinney DG, Disney MD. Small Molecule Inhibition of microRNA-210 Reprograms an Oncogenic Hypoxic Circuit. J Am Chem Soc. 2017. https://doi.org/10.1016/j.bbamc r.2010.06.013.

108. Bao L, Hazari S, Mehra S, Kaushal D, Moroz K, Dash S. Increased expression of P-glycoprotein and doxorubicin chemoresistance of metastatic breast cancer is regulated by miR-298. Am J Pathol. 2012. https://doi.org/10.1016/j. bbamcr.2010.06.013

109. Meng Y, Zou Q, Liu T, Cai X, Huang Y, Pan J. MicroRNA-335 inhibits proliferation, cell-cycle progression, colony formation, and invasion via targeting PAX6 in breast cancer cells. Mol Med Rep. 2015. https://doi.org/10.1016/j. bbamcr.2010.06.013.

110. Gao Y, Zeng F, Wu JY, Li HY, Fan JJ, Mai L, Zhang J, Ma DM, Li Y, Song F. MiR-335 inhibits migration of breast cancer cells through targeting oncoprotein c-Met. Tumor Biol. 2015. https://doi.org/10.1016/j.bbamcr.2010.06.013.

111. McAnena P, Tanriverdi K, Curran C, Gilligan K, Freedman JE, Brown JAL, Kerin MJ. Circulating microRNAs miR331 and miR-195 differentiate local luminal a from metastatic breast cancer. BMC Cancer. 2019. https://doi. org/10.1016/j.bbamcr.2010.06.013.

112. Yerukala Sathipati S, Ho SY. Identifying a miRNA signature for predicting the stage of breast cancer. Scientific Rep. 2018. https://doi.org/10.1016/j.bbamcr.2010.06.013.

113. Nassar FJ, Chamandi G, Tfaily MA, Zgheib NK, Nasr R. Peripheral Blood-Based Biopsy for Breast Cancer Risk Prediction and Early Detection. Blood. 2020. https://doi.org/10.1016/j.bbamcr.2010.06.013.

114. Loh HY, Norman BP, Lai KS, Rahman NM, Alitheen NBM, Osman MA. The regulatory role of microRNAs in breast cancer. Int J Mol Sci. 2019. https://doi.org/10.1016/j.bbamcr.2010.06.013.

115. Singh R, Mo YY. Role of microRNAs in breast cancer. Cancer. 2013. https://doi.org/10.1016/j.bbamcr.2010.06.013.

116. Zou D, Zhou Q, Wang D, Guan L, Yuan L, Li S. The downregulation of MicroRNA-10b and its Role in cervical cancer. Oncol Res. 2016. https://doi.org/10.1016/j.bbamcr.2010.06.013.

117. Hou R, Wang D, Lu J. MicroRNA-10b inhibits proliferation, migration and invasion in cervical cancer cells via direct targeting of insulin-like growth factor-1 receptor. Oncol Lett. 2017. https://doi.org/10.1016/j.bbamcr.2010.06.013.

118. Shukla V, Varghese VK, Kabekkodu SP, Mallya S, Chakrabarty S, Jayaram P, Pandey D, Banerjee S, Sharan K, Satyamoorthy K. Enumeration of deregulated miRNAs in liquid and tissue biopsies of cervical cancer. Gynecol Oncol. 2019. https://doi.org/10.1016/j.bbamcr.2010.06.013.

119. Jiménez-Wences H, Martínez-Carrillo DN, Peralta-Zaragoza O, Campos-Viguri GE, Hernández-Sotelo D, JiménezLópez MA, Muñoz-Camacho JG, Garzón-Barrientos VH, Illades-Aguiar B, Fernández-Tilapa G. Methylation and expression of miRNAs in precancerous lesions and cervical cancer with HPV16 infection. Oncol Rep. 2016. https:// doi.org/10.1016/j.bbamcr.2010.06.01313.

120. Zhao Y, Liu X, Lu Y. Microrna-143 regulates the proliferation and apoptosis of cervical cancer cells by targeting hif1 $\alpha$. Eur Rev Med Pharmacol Sci. 2017;21(24):5580-6.

121. Ma L, Hong Y, Lu C, Chen Y, Ma C. The occurrence of cervical cancer in Uygur women in Xinjiang Uygur Autonomous Region is correlated to microRNA-146a and ethnic factor. Int J Clin Exp Pathol. 2015;13(3):634.

122. Yang Z, Chen S, Luan X, Li Y, Liu M, Li X, Liu T, Tang H. MicroRNA-214 is aberrantly expressed in cervical cancers and inhibits the growth of hela cells. IUBMB Life. 2009. https://doi.org/10.1016/j.bbamcr.2010.06.01314.

123. Wang X, Xia Y. MicroRNA-328 inhibits cervical cancer cell proliferation and tumorigenesis by targeting TCF7L2. Biochem Biophys Res Commun. 2016. https://doi.org/10.1016/j.bbamcr.2010.06.01315. 
124. Wang Y, Dong $X$, Hu B, Jing Wang $X$, Wang $Q$, Wang W. The effects of Micro-429 on inhibition of cervical cancer cells through targeting ZEB1 and CRKL. Biomed Pharmacother. 2016. https://doi.org/10.1016/j.bbamc r.2010.06.01316.

125. Sun P, Shen Y, Gong JM, Zhou LL, Sheng JH, Duan FJ. A New MicroRNA Expression Signature for Cervical Cancer. Int J Gynecol Cancer. 2017. https://doi.org/10.1016/j.bbamcr.2010.06.01317.

126. Wen F, Xu JZ, Wang XR. Increased expression of miR-15b is associated with clinicopathological features and poor prognosis in cervical carcinoma. Arch Gynecol Obstetrics. 2017. https://doi.org/10.1016/j.bbamcr.2010.06.01318.

127. Xu J, Zhang W, Lv Q, Zhu D. Overexpression of miR-21 promotes the proliferation and migration of cervical cancer cells via the inhibition of PTEN. Oncol Rep. 2015. https://doi.org/10.1016/j.bbamcr.2010.06.01319.

128. Feng Y, Zhou S, Li G, Hu C, Zou W, Zhang H, Sun L. Nuclear factor- $k B$-dependent microRNA-130a upregulation promotes cervical cancer cell growth by targeting phosphatase and tensin homolog. Arch Biochem Biophys. 2016. https://doi.org/10.1016/j.bbamcr.2010.06.01320.

129. Zhang J, Wu H, Li P, Zhao Y, Liu M, Tang H. Nf-kb-modulated mir-130a targets tnf- $\alpha$ in cervical cancer cells. J Transl Med. 2014;12(1):155

130. Wang S, Gao B, Yang H, Liu X, Wu X, Wang W. MicroRNA-432 is downregulated in cervical cancer and directly targets FN1 to inhibit cell proliferation and invasion. Oncol Lett. 2019. https://doi.org/10.1016/j.bbamc r.2010.06.01321.

131. Nagy ZB, Wichmann B, Kalmár A, Galamb O, Barták BK, Spisák S, Tulassay Z, Molnár B. Colorectal adenoma and carcinoma specific miRNA profiles in biopsy and their expression in plasma specimens. Clin Epigenet. 2017. https ://doi.org/10.1016/j.bbamcr.2010.06.01322.

132. Lo UG, Yang D, Hsieh JT. The role of microRNAs in prostate cancer progression. Cancer. 2013. https://doi. org/10.1016/j.bbamcr.2010.06.01323.

133. Vanacore D, Boccellino M, Rossetti S, Cavaliere C, D'Aniello C, Di Franco R, Romano FJ, Montanari M, La Mantia E, Piscitelli R, Nocerino F, Cappuccio F, Grimaldi G, Izzo A, Castaldo L, Pepe MF, Malzone MG, lovane G, Ametrano G, Stiuso P, Quagliuolo L, Barberio D, Perdonà S, Muto P, Montella M, Maiolino P, Veneziani BM, Botti G, Caraglia M, Facchini G. Micrornas in prostate cancer: an overview. Oncotarget. 2017. https://doi.org/10.1016/j.bbamc r.2010.06.01324.

134. Hoey C, Ahmed M, Fotouhi Ghiam A, Vesprini D, Huang X, Commisso K, Commisso A, Ray J, Fokas E, Loblaw DA, $\mathrm{He} \mathrm{HH}$, Liu SK. Circulating miRNAs as non-invasive biomarkers to predict aggressive prostate cancer after radical prostatectomy. J Transl Med. 2019. https://doi.org/10.1016/.jbbamcr.2010.06.01325.

135. Murata T, Takayama K, Katayama S, Urano T, Horie-Inoue K, Ikeda K, Takahashi S, Kawazu C, Hasegawa A, Ouchi Y, Homma Y, Hayashizaki Y, Inoue S. miR-148a is an androgen-responsive microRNA that promotes LNCaP prostate cell growth by repressing its target CAND1 expression. Prostate Cancer Prostatic Dis. 2010. https://doi. org/10.1016/j.bbamcr.2010.06.01326.

136. Nip H, Dar AA, Saini S, Colden M, Varahram S, Chowdhary H, Yamamura S, Mitsui Y, Tanaka Y, Kato T, Hashimoto Y, Shiina M, Kulkarni P, Dasgupta P, Imai-Sumida M, Laura Tabatabai Z, Greene K, Deng G, Dahiya R, Majid S. Oncogenic microRNA-4534 regulates PTEN pathway in prostate cancer. Oncotarget. 2016. https://doi.org/10.1016/j. bbamcr.2010.06.01327.

137. Zuo ZH, Yu YP, Ding Y, Liu S, Martin A, Tseng G, Luo JH. Oncogenic Activity of miR-650 in Prostate Cancer Is Mediated by Suppression of CSR1 Expression. Am J Pathol. 2015. https://doi.org/10.1016/j.bbamcr.2010.06.01328.

138. Qingchuan D, Ping M, Tao W, Weiwei Q, Weijun Q, Fuli W, Jianlin Y, Zhinan C, Angang Y, He W. MicroRNA let-7a inhibits proliferation of human prostate cancer cells In Vitro and In Vivo by targeting E2F2 and CCND2. PLoS ONE. 2010. https://doi.org/10.1016/j.bbamcr.2010.06.01329.

139. Nadiminty N, Tummala R, Lou W, Zhu Y, Shi XB, Zou JX, Chen H, Zhang J, Chen X, Luo J, deVere White RW, Kung HJ, Evans CP, Gao AC. MicroRNA let-7c is downregulated in prostate cancer and suppresses prostate cancer growth. PLoS ONE. 2012. https://doi.org/10.1016/j.bbamcr.2010.06.01330.

140. Sung SY, Liao CH, Wu HP, Hsiao WC, Wu IH, Jinpu Yu, Lin SH, Hsieh CL. Loss of let-7 microRNA upregulates IL-6 in bone marrow-derived mesenchymal stem cells triggering a reactive stromal response to prostate cancer. PloS one. 2013. https://doi.org/10.1371/journal.pone.0071637

141. Wang M, Ren D, Guo W, Wang Z, Huang S, Du H, Song L, Peng X. Loss of miR-100 enhances migration, invasion, epithelial-mesenchymal transition and stemness properties in prostate cancer cells through targeting Argonaute 2. Int J Oncol. 2014. https://doi.org/10.1016/j.bbamcr.2010.06.01331.

142. Zhang W, Mao YQ, Wang H, Yin WJ, Zhu SX, Wang WC. MiR-124 suppresses cell motility and adhesion by targeting talin 1 in prostate cancer cells. Cancer Cell Int. 2015. https://doi.org/10.1016/j.bbamcr.2010.06.01332.

143. Qin W, Pan Y, Zheng X, Li D, Bu J, Xu C, Tang J, Cui R, Lin P, Yu X. MicroRNA-124 regulates TGF- $\alpha$-induced epithelialmesenchymal transition in human prostate cancer cells. Int J Oncol. 2014. https://doi.org/10.1016/j.bbamc r.2010.06.01333.

144. Shi XB, Xue L, Yang J, Ma AH, Zhao J, Xu M, Tepper CG, Evans CP, Kung HJ, White RWDV. An androgen-regulated miRNA suppresses Bak1 expression and induces androgen-independent growth of prostate cancer cells. Proc Natl Acad Sci USA. 2007. https://doi.org/10.1016/j.bbamcr.2010.06.01334.

145. Shi XB, Xue L, Ma AH, Tepper CG, Kung HJ, White RWD. MiR-125b promotes growth of prostate cancer xenograft tumor through targeting pro-apoptotic genes. Prostate. 2011. https://doi.org/10.1016/j.bbamcr.2010.06.01335.

146. Fu W, Tao T, Qi M, Wang L, Hu J, Li X, Xing N, Du R, Han B. MicroRNA-132/212 Upregulation Inhibits TGF- $\beta$-Mediated Epithelial-Mesenchymal Transition of Prostate Cancer Cells by Targeting SOX4. Prostate. 2016. https://doi. org/10.1016/j.bbamcr.2010.06.01336.

147. Zhang HL, Qin XJ, Cao DL, Zhu Y, Yao XD, Zhang SL, Dai B, Ye DW. An elevated serum miR-141 level in patients with bone-metastatic prostate cancer is correlated with more bone lesions. Asian J Androl. 2013. https://doi. org/10.1016/j.bbamcr.2010.06.01337.

148. Zhou P, Chen WG, Li XW. MicroRNA-143 acts as a tumor suppressor by targeting hexokinase 2 in human prostate cancer. Am J Cancer Res. 2015:9:12 
149. Xu B, Niu X, Zhang X, Tao J, Wu D, Wang Z, Li P, Zhang W, Wu H, Feng N, Wang Z, Hua L, Wang X. MiR-143 decreases prostate cancer cells proliferation and migration and enhances their sensitivity to docetaxel through suppression of KRAS. Mol Cell Biochem. 2011. https://doi.org/10.1016/j.bbamcr.2010.06.01338.

150. Guo W, Ren D, Chen X, Tu X, Huang S, Wang M, Song L, Zou X, Peng X. HEF1 promotes epithelial mesenchymal transition and bone invasion in prostate cancer under the regulation of microRNA-145. J Cell Biochem. 2013. https://doi.org/10.1016/j.bbamcr.2010.06.01339.

151. Chen X, Gong J, Zeng H, Chen N, Huang R, Huang Y, Nie L, Xu M, Xia J, Zhao F, Meng W, Zhou Q. MicroRNA145 targets BNIP3 and suppresses prostate cancer progression. Cancer Res. 2010. https://doi.org/10.1016/j.bbamc r.2010.06.01340.

152. Zhang X, Tao T, Liu C, Guan H, Huang Y, Xu B, Chen M. Downregulation of miR-195 promotes prostate cancer progression by targeting HMGA1. Oncol Rep. 2016. https://doi.org/10.1016/j.bbamcr.2010.06.01341.

153. Wu J, Ji A, Wang X, Zhu Y, Yu Y, Lin Y, Liu Y, Li S, Liang Z, Xu X, Zheng X, Xie L. MicroRNA-195-5p, a new regulator of Fra-1, suppresses the migration and invasion of prostate cancer cells. J Transl Med. 2015. https://doi. org/10.1016/j.bbamcr.2010.06.01342.

154. Liu X, Chen Q, Yan J, Wang Y, Zhu C, Chen C, Zhao X, Xu M, Sun Q, Deng R, Zhang H, Qu Y, Huang J, Jiang B, Yu J. MiRNA-296-3p-ICAM-1 axis promotes metastasis of prostate cancer by possible enhancing survival of natural killer cell-resistant circulating tumour cells. Cell Death Dis. 2013. https://doi.org/10.1016/j.bbamc r.2010.06.01343.

155. Rasheed SAK, Teo CR, Beillard EJ, Voorhoeve PM, Casey PJ. MicroRNA-182 and MicroRNA-200a control G-protein subunit $\alpha-13$ (GNA13) expression and cell invasion synergistically in prostate cancer cells. J Biol Chem. 2013. https://doi.org/10.1016/j.bbamcr.2010.06.01344.

156. Galardi S, Mercatelli N, Giorda E, Massalini S, Frajese GV, Ciafrè SA, Farace MG. miR-221 and miR-222 expression affects the proliferation potential of human prostate carcinoma cell lines by targeting p27Kip1. J Biol Chem. 2007. https://doi.org/10.1016/..bbamcr.2010.06.01345.

157. Zheng C, Yinghao S, Li J. MiR-221 expression affects invasion potential of human prostate carcinoma cell lines by targeting DVL2. Med Oncol. 2012;29(2):815-22. https://doi.org/10.1016/j.bbamcr.2010.06.01346.

158. Yang X, Yang Y, Gan R, Zhao L, Li W, Zhou H, Wang X, Lu J, Meng QH. Down-regulation of miR-221 and miR-222 restrain prostate cancer cell proliferation and migration that is partly mediated by activation of SIRT1. PLOS ONE. 2014. https://doi.org/10.1016/j.bbamcr.2010.06.01347.

159. Wei JJ, Wu X, Peng Y, Shi G, Olca B, Yang X, Daniels G, Osman I, Ouyang J, Hernando E, Pellicer A, Rhim JS, Melamed J, Lee P. Regulation of HMGA1 expression by MicroRNA-296 affects prostate cancer growth and invasion. Clinical Cancer Res. 2011. https://doi.org/10.1016/j.bbamcr.2010.06.01348.

160. Lee KH, Lin FC, Hsu TI, Lin JT, Guo JH, Tsai CH, Lee YC, Lee YC, Chen CL, Hsiao M, Lu PJ. MicroRNA-296-5p (miR-296-5p) functions as a tumor suppressor in prostate cancer by directly targeting Pin1. Biochimica et Biophysica Acta. 2014. https://doi.org/10.1016/j.bbamcr.2010.06.01349.

161. Wen J, Li R, Wen X, Chou G, Lu J, Wang X, Jin Y. Dysregulation of cell cycle related genes and microRNAs distinguish the low- from high-risk of prostate cancer. Diagnostic Pathol. 2014. https://doi.org/10.1186/s1300 0-014-0156-1.

162. Bryant RJ, Pawlowski T, Catto JWF, Marsden G, Vessella RL, Rhees B, Kuslich C, Visakorpi T, Hamdy FC. Changes in circulating microRNA levels associated with prostate cancer. Br J Cancer. 2012. https://doi.org/10.1038/bjc.2011.595.

163. Zhang W, Liu J, Qiu J, Fu X, Tang Q, Yang F, Zhao Z, Wang H. MicroRNA-382 inhibits prostate cancer cell proliferation and metastasis through targeting COUP-TFIl. Oncol Rep. 2016. https://doi.org/10.3892/or.2016.5141.

164. Noonan EJ, Place RF, Pookot D, Basak S, Whitson JM, Hirata H, Giardina C, Dahiya R. MiR-449a targets HDAC-1 and induces growth arrest in prostate cancer. Oncogene. 2009. https://doi.org/10.1016/j.bbamcr.2010.06.01353.

165. Noonan EJ, Place RF, Basak S, Pookot D, Li LC. miR-449a causes Rb-dependent cell cycle arrest and senescence in prostate cancer cells. Oncotarget. 2010. https://doi.org/10.1016/j.bbamcr.2010.06.01354.

166. Mariotto AB, Robin Yabroff K, Shao Y, Feuer EJ, Brown ML. Projections of the cost of cancer care in the United States: 2010-2020. J Natl Cancer Inst. 2011. https://doi.org/10.1093/jnci/djq495.

167. Dusetzina SB. Drug pricing trends for orally administered anticancer medications reimbursed by commercial health plans, 2000-2014. JAMA Oncol. 2016. https://doi.org/10.1001/jamaoncol.2016.0648.

168. Dolgin E. Bringing down the cost of cancer treatment. Nature. 2018. https://doi.org/10.1016/j.bbamc r.2010.06.01357.

169. Atun R, Cavalli F. The global fight against cancer: challenges and opportunities. Lancet. 2018. https://doi. org/10.1016/S0140-6736(18)30156-9.

170. Massuda A, Hone T, Leles FAG, De Castro MC, Atun R. The Brazilian health system at crossroads: Progress, crisis and resilience. BMJ Global Health. 2018. https://doi.org/10.1016/j.bbamcr.2010.06.01359.

171. Liu R, Li J, Lai Y, Liao Y, Liu R, Qiu W. Hsa-miR-1 suppresses breast cancer development by down-regulating K-ras and long non-coding RNA MALAT1. Int J Biol Macromol. 2015. https://doi.org/10.1016/j.jijbiomac.2015.08.016.

172. Yan L, Yu MC, Gao GL, Liang HW, Zhou XY, Zhu ZT, Zhang CY, Wang YB, Chen X. MiR-125a-5p functions as a tumour suppressor in breast cancer by downregulating BAP1. J Cell Biochem. 2018. https://doi.org/10.1002/jcb.27124.

173. Ru P, Steele R, Hsueh EC, Ray RB. Anti-mir-203 upregulates socs3 expression in breast cancer cells and enhances cisplatin chemosensitivity. Genes Cancer. 2011;2(7):720-7.

174. Camps C, Saini HK, Mole DR, Choudhry H, Reczko M, Guerra-Assunção JA, Tian YM, Buffa FM, Harris AL, Hatzigeorgiou AG, Enright AJ, Ragoussis J. Integrated analysis of microRNA and mRNA expression and association with HIF binding reveals the complexity of microRNA expression regulation under hypoxia. Mol Cancer. 2014. https://doi. org/10.1186/1476-4598-13-28.

175. Zhang Y, Yan J, Wang L, Dai H, Li N, Hu W, Cai H. HIF-1 $\alpha$ Promotes Breast Cancer Cell MCF-7 Proliferation and Invasion Through Regulating miR-210. Cancer Biother Radiopharm. 2017. https://doi.org/10.1089/cbr.2017.2270.

176. Mohammadi-Yeganeh S, Paryan M, Arefian E, Vasei M, Ghanbarian H, Mahdian R, Karimipoor M, Soleimani M. MicroRNA-340 inhibits the migration, invasion, and metastasis of breast cancer cells by targeting Wnt pathway. Tumor Biol. 2016. https://doi.org/10.1007/s13277-015-4513-9. 
177. Yao J, Deng B, Zheng L, Dou L, Guo Y, Guo K. MiR-27b is upregulated in cervical carcinogenesis and promotes cell growth and invasion by regulating CDH11 and epithelial-mesenchymal transition. Oncol Rep. 2016. https://doi. org/10.3892/or.2015.4500.

178. Miska EA, Alvarez-Saavedra E, Townsend M, Yoshii A, Sestan N, Rakic P, Constantine-Paton M, Horvitz HR. Microarray analysis of microRNA expression in the developing mammalian brain. Genome Biol. 2004. https://doi.org/10.1186/ gb-2004-5-9-r68.

179. LiW, Ruan K. MicroRNA detection by microarray. Anal Bioanal Chem. 2009. https://doi.org/10.1007/s0021 6-008-2570-2.

180. Wu Q, Lu Z, Li H, Lu J, Guo L, Ge Q. Next-generation sequencing of microRNAs for breast cancer detection. J Biomed Biotechnol. 2011. https://doi.org/10.1155/2011/597145.

181. Leshkowitz D, Horn-Saban S, Parmet Y, Feldmesser E. Differences in microRNA detection levels are technology and sequence dependent. RNA. 2013. https://doi.org/10.1016/j.bbamcr.2010.06.01369.

182. Várallyay É, Burgyán J, Havelda Z. MicroRNA detection by northern blotting using locked nucleic acid probes. Nature Protocols. 2008. https://doi.org/10.1016/j.bbamcr.2010.06.01370.

183. Koscianska E, Starega-Roslan J, Sznajder LJ, Olejniczak M, Galka-Marciniak P, Krzyzosiak WJ. Northern blotting analysis of microRNAs, their precursors and RNA interference triggers. BMC Mol Biol. 2011. https://doi. org/10.1186/1471-2199-12-14.

184. Jia H, Li Z, Liu C, Cheng Y. Ultrasensitive detection of microRNAs by exponential isothermal amplification. Angewandte Chemie. 2010. https://doi.org/10.1002/anie.201001375.

185. Duan R, Zuo X, Wang S, Quan X, Chen D, Chen Z, Jiang L, Fan C, Xia F. Lab in a tube: Ultrasensitive detection of MicroRNAs at the single-cell level and in breast cancer patients using quadratic isothermal amplification. J Am Chem Soc. 2013. https://doi.org/10.1021/ja311313b.

186. Deng R, Zhang K, Li J. Isothermal Amplification for MicroRNA Detection: From the Test Tube to the Cell. Acc Chem Res. 2017. https://doi.org/10.1021/acs.accounts.7b00040.

\section{Publisher's Note}

Springer Nature remains neutral with regard to jurisdictional claims in published maps and institutional affiliations.

- fast, convenient online submission

- thorough peer review by experienced researchers in your field

- rapid publication on acceptance

- support for research data, including large and complex data types

- gold Open Access which fosters wider collaboration and increased citations

- maximum visibility for your research: over 100M website views per year

At BMC, research is always in progress.

Learn more biomedcentral.com/submissions 